\title{
Interaction of Turkey and World Trade within the Framework of the World Trade Organization
}

\author{
Selma Aytüre $^{1 *}$ - Ahmet Yücel ${ }^{2}$ \\ ${ }^{1}$ Faculty of Applied Sciences, Ankara Y1ldirim Beyazit University, Ankara, 06950,TURKEY \\ ${ }^{2}$ Faculty of Applied Sciences, Ankara Y1ldirim Beyazit University, Ankara, 06950,TURKEY
}

\begin{abstract}
The level and direction of the relationship between WT (World Trade) and TFT (Turkey Foreign Trade) statistically analysed in this study. For this purpose, in addition to some descriptive statistics, correlation and regression algorithms were utilized to observe the relationship. In addition, point, box and line graphs were used to observe the relative distributions of WT and TFT. According to the results, there is a $99.258 \%$ correlation between WT and TFT. In addition, a linear regression model was designed in which TFT was determined as dependent and WT was determined as independent variable. The model is statistically significant at a confidence level of 0.05 and R, R-square and adj.-R-square explanatory ability rates of the model are $99.2 \%, 98.5 \%$ and $98.4 \%$, respectively. The scatter-plot shows that the binary value points are generally distributed around the linear line. In the box-plot, it is observed that WT has a wider range than TFT, but generally both variables have a symmetrical distribution. Finally, the line graph shows the ordered and consequetive 38-year distribution of both variables. Although the distribution is generally parallel to each other, the upward movement of WT has been observed to be sharper and accelerated in the last 10 years. All these results indicate that TFT has a very strong level of relationship with WT and that WT can be used as an important parameter in understanding TFT.
\end{abstract}

Keywords: World Trade Organisation (WTO), Turkey, World Trade (WT), Turkey Foreign Trade (TFT),

\section{Introduction}

In order to eliminate the negative economic and political effects of the Second World War, economic measures that can be taken through international negotiations came at the forefront of the solutions sought. . It was necessary to regulate world trade in order to develop the economies of the countries and to eliminate the war environment and the damages of the war thanks to the increasing prosperity. In line with this requirement, it is aimed to bring order to the world economy with the participation of many countries as discussed in Argin \& Bakkalc1 1 (2011).

After the Second World War, the United Nations adopted a very elaborate agreement on tariffs (General Agreement on Tariffs and Trade: G.A.T.T.) in Geneva (1947). In this, principles were determined for a measured customs policy, the durations of preference rights were determined and the excesses were softened. But a year later, in Havana, a project that envisaged high commercial goals was rejected by the resistance of the patronage group (1948). The free economy has suffered many blows throughout history, but it still managed to get rid of all of them as discussed in Sedillot 2 (2005).

In more than 60 years since its establishment, a total of 8 rounds of multilateral free trade negotiations, some of which took many years to complete, have been held: 1) Geneva Tour (1947), 2) Annecy Round (1949), 3) Torquay Tour (1950). -51), 4) Geneva Tour (1956), 5) Dillon Tour (1960-61), 6) Kennedy Tour (1964-67), 7) Tokyo Tour (1973-79), 8) Uruguay Tour (1986-93) ). The ninth and last of these rounds started in Doha, Qatar in 2000 and is referred to as the Doha Round, Millennium Round or Doha Development Agenda. The negotiations in the previous round, the Uruguay Round, were completed at the end of 1993, and the agreed free 
trade agreement was signed in Marrakech, Morocco on April 15, 1994, with the participation of 111 countries, and entered into force. With this agreement, GATT ended and was replaced by the World Trade Organization (WTO) as of January 1, 1995. In every round of negotiations held until that date, significant successes have been achieved, especially in terms of liberalization of trade in industrial products.

In the Doha Round (DR), also called the "Millennium round" or the Doha Development Round, agricultural issues play a significant role in the negotiations between the trade blocs. Among the main agenda items of the DR are the issues that the Uruguay Round failed to resolve. In this context, issues such as the environment, labor exploitation, market access, state-sponsored trade, agricultural support policies, export subsidies, technical barriers and health standards, and dispute resolution mechanisms can be counted among the most important items on the agenda.

The WTO is a follower of the Uruguay Round agreements, a forum in which the direction of international trade is determined, an organ where member countries resolve their trade problems without resorting to unilateral measures, and a functional organization that mediates and assists the integration of developing countries with the multilateral trade system. Significant majority of the decisions is taken on a "consensus" basis by the Permanent Representatives/Ambassadors, who are assigned at the Ministerial Conference, which meets at least every two years, with the participation of all member states, or at the member's missions in Geneva, and who meet regularly under the name of the General Council.

The current number of members of the Organization is 164, and membership negotiations are ongoing for approximately 23 countries. Besides the General Council, which carries out the regular work of the Organization in Geneva, there are several technical committees that deal with technical and other issues related to the WTO Agreements. One of the most important units is Dispute Settlement Body (DSB). If WTO members cannot resolve their trade disputes through bilateral negotiations, it is possible to take them to the DSB. DSB's decision on any commercial dispute is binding. Its secretariat is in Geneva.

Turkey signed the agreement establishing the WTO in Marrakech at the end of the Uruguay Round. She became a founding member of the WTO as of March 26, 1995, with the decision of the Council of Ministers issued in this context. Turkey, which is among the WTO members, has fulfilled its commitments stipulated in the "Uruguay Round" agreements. Turkey is included in the Developing Country Group (MFA 3, 2021).

\section{World Trade Organization}

The main functions of the Organization: Ensuring the implementation and supervision of the multilateral and multilateral trade agreements constituting the WT; Establishing a forum for multilateral trade negotiations; To monitor the national trade policies of the member countries; To ensure cooperation with other international organizations related to global economic policy; To assist developing and transition economies to integrate with the multilateral trading system.

The basic principles of the WTO are: Non-discrimination; Most favored nation (MFN); National treatment (NT); Reciprocity; Transparency; Communications, trade policy review, etc.; Binding commitments; Connecting tariffs and converting non-tariff barriers to tariffs (Safety valves); Protection provisions, antidumping etc. (WTO 4, 2021).

Turkey, which is among the WTO members, has fulfilled its commitments stipulated in the "Uruguay Round" agreements. Although Turkey is in the WTO's group of Developing Countries (DEs), it goes far beyond the Uruguay Round commitments within the framework of the Customs Union completed with the EU as of 01.01.1996 and is ahead of other member DEs in liberalizing international trade.

According to Akman 5 (2016), the most important development in terms of authority was experienced during the multilateral negotiations of the Uruguay Round, which continued in the 1990s. Until then, the EU had rather a disposition on the trade of goods. In general, since the regulations and negotiations in the context of the GATT consisted of trade in goods and especially the reduction of customs tariffs on industrial products and the handling of protection measures, there was a prevailing opinion that trade policy should also be limited to 
the aforementioned traditional areas. However, within the framework of the Uruguay Round, especially trade in services and trade related intellectual property rights were also included in the negotiation agenda. After the negotiations in this Round, the General Agreement on Trade in Services (GATS) and the Trade-Related Intellectual Property Rights Agreement (TRIPS) on the liberalization of trade in services had to be signed together with all other regulation and liberalization commitments within the Tour package.

Agriculture, which had a privileged position for nearly 50 years until 1994, when the Uruguay Round Agreement was signed, was included in the scope of free trade negotiations with the Uruguay Round Agreement. In the agreement, arrangements were made to reduce the support given by both developed and developing countries to the production and trade of agricultural products. During and immediately after the Uruguay Round negotiations, many countries, especially the EU and the USA, sought new policies in agriculture or accelerated their search for reforms that they had started before. By enacting a new agricultural support program in 1996, the USA made direct income support payments independent of production the main support tool. The EU was not satisfied with the reform it made in 1992, and it was foreseen to take some measures to reduce the burden of agricultural support on the budget and to bring prices closer to world prices with the Agenda 2000 report in Acar \& Aytüre 6 (2014).

As discussed in Aytüre \& Acar 7 (2018), in Turkey, in the 2000s, many important actions were taken on agricultural policies, the foundations of which were laid in the 1980s, and the process of change and transformation that was entered thirty years ago continued. Among the important services put into use in this period are the preparation of the Agriculture Strategy Document, the enactment of the Agriculture Law, and the studies on harmonization with the EU. In this context, the Farmer Registration System was put into use, support policies were revised in line with WTO and EU norms, support payments were recorded, thus Turkey registered the agricultural sector seriously for the first time. Again, one of the important services made in this period is the structural transformation studies in agriculture.

After the Uruguay Round, an irreversible path has been embarked towards greater liberalization on agricultural subsidies and the future of agricultural trade. It is worth emphasizing that the traditional area of comparative advantage in most developing countries is agriculture. The sectors in which developed countries are the most protective are the agricultural sectors. In this context, it is in the interest of developing countries to act together in WTO negotiations both on the liberalization of agricultural trade and other issues, against major actors such as the EU and the USA, who do not want to give up the overprotectionism in agriculture easily or who want to carry out the liberalization process completely under their own control. As a matter of fact, it has been observed that developing countries have grasped this point since the 1999 Seattle meetings and started to organize and act together in line with their own interests according to Acar 8 (2006).

Making a special reference to the development dimension with the support from the USA and other countries, the Doha Tour officially started in November 2001. Although the Doha Development Agenda work program covered a wide area, it was not successful and could not be completed in 2004, which was originally envisaged. After the Cancun meeting in 2003, there was a tendency to narrow down the working subjects, and from the "framework" decision adopted in July 2004, the main topics of negotiation were agriculture, market entry in non-agricultural products (NAMA), services trade and trade facilitation. However, the Doha Round negotiations were suspended in 2006, as the draft modalities to be applied on the main topics, especially tariff reductions and liberalization, could not be determined and the disagreements could not be resolved. After this date, with the initiatives of WTO Director-General P.Lamy, draft modalities were prepared and a process in which member states were encouraged to continue the negotiation process was entered. However, objections continued to these draft texts on reductions in both agriculture and NAMA. As of today, the Doha Tour has been inconclusive; however, almost all parties, especially the EU, continued to make statements on the continuity of this process and the importance of completing the Tour in terms of development and welfare increase (Akman 5, 2016). 
In general, the differences between the negotiation positions of the member states during the Doha Round played an important role in the stagnation of the Round. Doha trade negotiations have become a dynamic and multidimensional process in which the internal interactions between the parties and among themselves are reflected, beyond being just a North/South struggle in general terms. The steps taken for the development of the Tour, which was started with "development" oriented goals, remained modest (Tepav 9, 2008).

The agriculture negotiations held within the scope of the Doha Tour, many meetings, workshops, Ministerial conferences etc. have been held for this purpose since 2001 carried out, but no conclusion has yet been reached. The negotiations follow a course of development depending on the political agendas of major players such as the EU and the USA and the importance given by the administrations to this issue. It is possible that the negotiations, which still follow a slow course, will accelerate and come to a conclusion in the future according to the signals from Europe and America. Agricultural product trade and the type, nature and scope of the support to be given to agricultural products will occupy the world agenda in the next period (Acar \& Aytüre 6, 2014).

Although there is a general agreement that global trade and the WTO system have problems, it does not seem possible to provide a broad consensus on why the problems arise. The free trade view, which is the main target of the WTO/GATT idea, is subject to serious erosion. As a matter of fact, one of the important reasons behind the slowness of the parties in terms of reconciliation, despite the gains from the Doha Round, is that the interest in liberalization in trade has recently started to decrease (Tepav 9, 2008:37).

The fact that the Doha Round could not be concluded despite the long period of time has brought with it the concern that it will cause serious erosion on the WTO multilateral system. It is seen that a series of decisions, especially the Trade Facilitation Agreement (TFA) taken after the 9th WTO Ministerial Conference in 2013, have somewhat eliminated this concern. The 10th WTO Ministerial Conference held at the end of 2015 is an important step where some decisions were taken especially for the benefit of the least developed countries (LDC). However, it was emphasized that the EU, which kept its hope that the Doha Tour could be completed at every opportunity and strategy until this meeting, would not insist on the Doha Tour, as it was expressed for the first time in the Nairobi Conference Declaration. From this point of view, it is understood that the EU will focus more on alternative trade negotiations with the USA and Japan from now on (Akman 5, 2016).

As a result of this process; Trade Facilitation Agreement" was adopted at the 9th WTO Ministerial Conference held in Bali/Indonesia on 7 December 2014. Subsequently, with the decision of the WTO General Council convened on 27 November 2014, the amendment protocol to add the Trade Facilitation Agreement to the Marrakech Agreement was accepted and the Agreement was opened for acceptance by the member states. The Trade Facilitation Agreement entered into force globally on February 22, 2017, after 2/3 of the 164 WTO member countries completed the ratification process.

Agreement consists of 3 chapters, 24 articles and 1 appendix. In the first part of the agreement, which includes the first 12 articles, Articles 1 to 5 are GATT Article X on the transparency and predictability of commercial legislation, Articles 6 to 10 are GATT Article VIII on fees and formalities, and Article 11 is on freedom of transit. GATT Article V is explanatory. Article 12, on the other hand, establishes a cooperation mechanism that enables information exchange between the customs administrations of the WTO member countries.

In this regard, in the first part of the Agreement, which includes the first 12 articles, there are technical provisions for trade facilitation, summarized below. The second part of the Agreement, titled "Special and Favorable Treatment for Developing Countries (DEs) and Least Developed Countries (LDCs)" covering Articles 13 to 22 of the Agreement, covers the provision of capacity building assistance and support for developing countries (LDCs) and LDCs in order to implement their obligations. contains. In the last part of the agreement, institutional arrangements are included in article 23 and final provisions in article 24 .

With the Law No. 6662 dated 15.01.2016, the "Protocol Amending the Marrakech Agreement Establishing the WTO" and the "Trade Facilitation Agreement" annexed to the said Protocol were approved. The said Protocol 
and its annexed Agreement were approved by the Council of Ministers Decision dated 29.02.2016 and numbered 2016/8570.

Article 23 of the Trade Facilitation Agreement envisages the establishment of a "National Trade Facilitation Committee" in WTO member countries in order to facilitate the implementation of the provisions of the Agreement within the country and to ensure effective coordination between relevant institutions. In this context, the Trade Facilitation Board was established with the (repealed) Prime Ministry Circular dated 3 December 2016 and numbered 2016/27. Trade Facilitation Board; It has assumed the role of a platform that will ensure coordination and cooperation between public institutions and private sector organizations on trade facilitation and implement positive trade facilitation reforms. In this context, the Board aims to contribute to the planning and effective implementation of trade facilitation measures, ensuring coordination between our actors responsible for transboundary trade transactions, taking into account the needs of the private sector and determining the steps to be taken in this context, as well as the implementation of the provisions of the WTO Trade Facilitation Agreement. (MT 10, 2019).

As discussed in Öztürk 11 (2018), the World Trade Organization, which includes developed countries, developing countries and underdeveloped countries, carries out almost all of the world trade activities alone today. Its effectiveness is increased by making updates with its ever-expanding range.

As can be seen, the obstacles to the liberalization of trade are being overcome one by one, and world trade is developing and increasing rapidly. This trend also positively affects Turkey's foreign trade.

\section{The Relationship between World Trade (WT) and Turkey Foreign Trade (TFT)}

In this study, the level and direction of the relationship between WT and TFT were statistically investigated. For this purpose, in addition to some descriptive statistics, correlation calculations and regression relationships were used to observe the relationship. In addition, scatter-plots, box-plots and line-plots were used to observe the relative distributions of WT and TFT. The results show that there is a $99.258 \%$ positive (directly proportional) correlation between WT and TFT. In addition, a linear regression model was created in which TFT was determined as the dependent variable and WT as the independent variable. The model is statistically significant at 0.05 confidence level, and the performance rates of the model in explaining the relevant data were $99.2 \%, 98.5 \%$, and $98.4 \%$ for R, R-squared, and adj. R-squared, respectively. In the scatter plot, it can be observed that the points of the binary values are generally distributed around the line. In the boxplot, it can be seen that the WT has a wider range than the TFT, but in general, both variables have a nearly symmetrical distribution. Finally, the line plot shows the distribution of the 38-year values of both variables. Although in general there is a parallel distribution, it was found that the upward movement of the WT was stronger and faster in the last 10 years.

As explained in Aytüre \& Yücel 13 (2019), world trade data (wto 4, 2019) are expressed by the X variable and Turkey's foreign trade data (tuik 12, 2019) by the Y variable. Table 1 presents the relevant descriptive statistics for the data over a 38-year period.

Table 1: Descriptive Statistics (DATA_1980-2017_TRADE)

\begin{tabular}{ll}
\hline $\mathbf{X}: \mathbf{W T}$ & Y: $\mathbf{T F T}$ \\
\hline $\mathrm{N}=38$ & $\mathrm{~N}=38$ \\
Mean $=785,134,157,894.7$ & $\mathrm{Mean}=143,696,300,139.4$ \\
Std.D. $=511,712,211,271.9$ & Std.D. $=141,481,126,037.6$ \\
Max. $=1,752,575,000,000$ & Max. $=403,463,887,000$ \\
Min. $=265,517,000,000$ & Min. $=10,819,485,700$ \\
\hline
\end{tabular}


Figure 1: Scatter-Plot
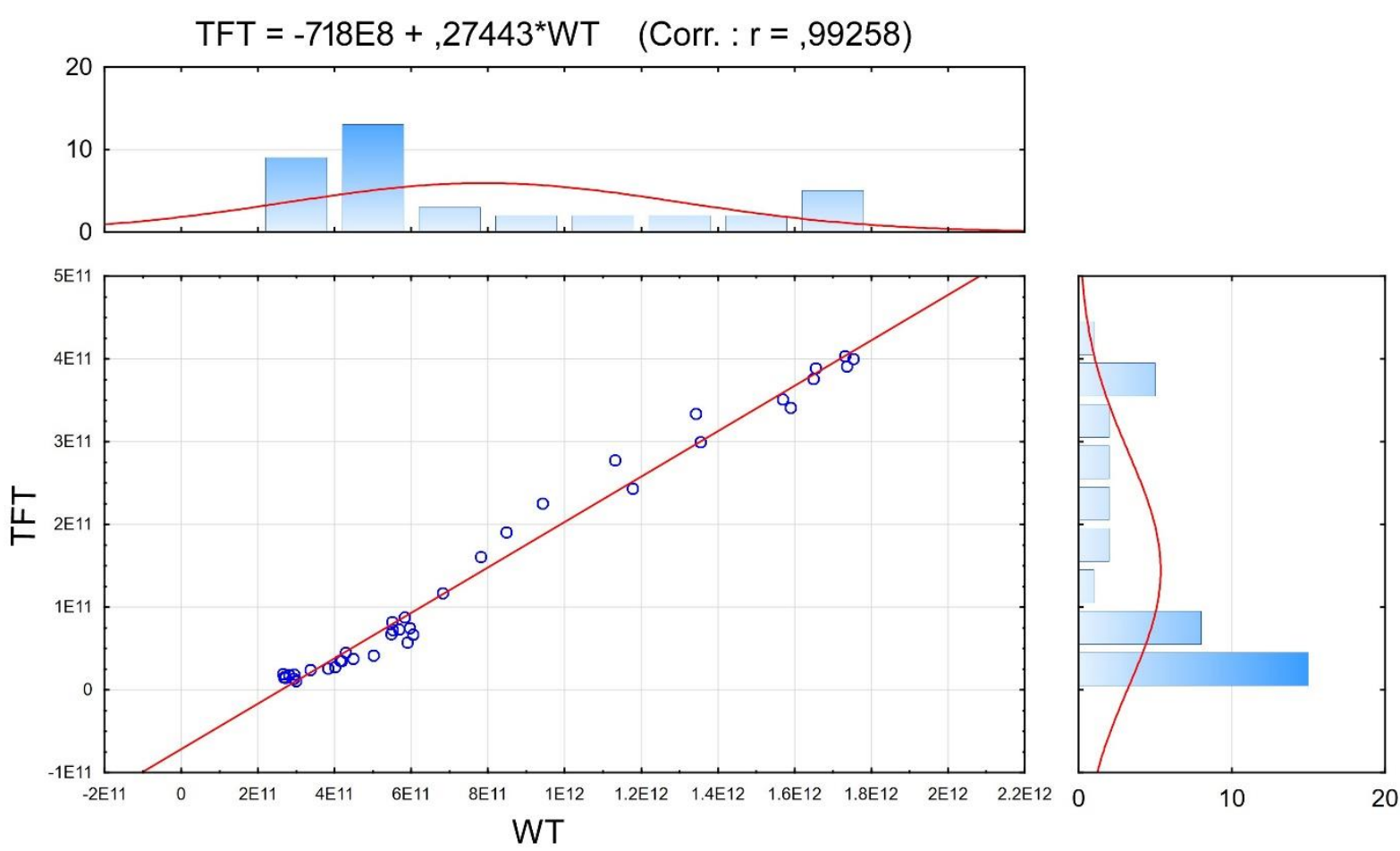

Figure 1 shows the one-year distribution of TFT and WT values in a point distribution diagram. In general, it can be observed that the two values have a proportional and parallel distribution pattern. Moreover, the unitwise distributions of TFT and WT are shown in the same figure. The respective distribution is classified according to the length of the value interval and presented in the frequency distribution table. It can be observed that TFT has a left-skewed distribution and WT has a right-skewed distribution.

\section{Figure 2: Box-Plot}



Figure 2 shows the interval lengths and unit-based distributions for both variables comparatively. The box plot was used because it allows the comparison of the variables at the level of the central tendency measures. No outlier can be seen for both TFT and WT. In addition, the WT appears to have a wider range than the TFT. 
Figure 3: Line-Plot of multiple variables

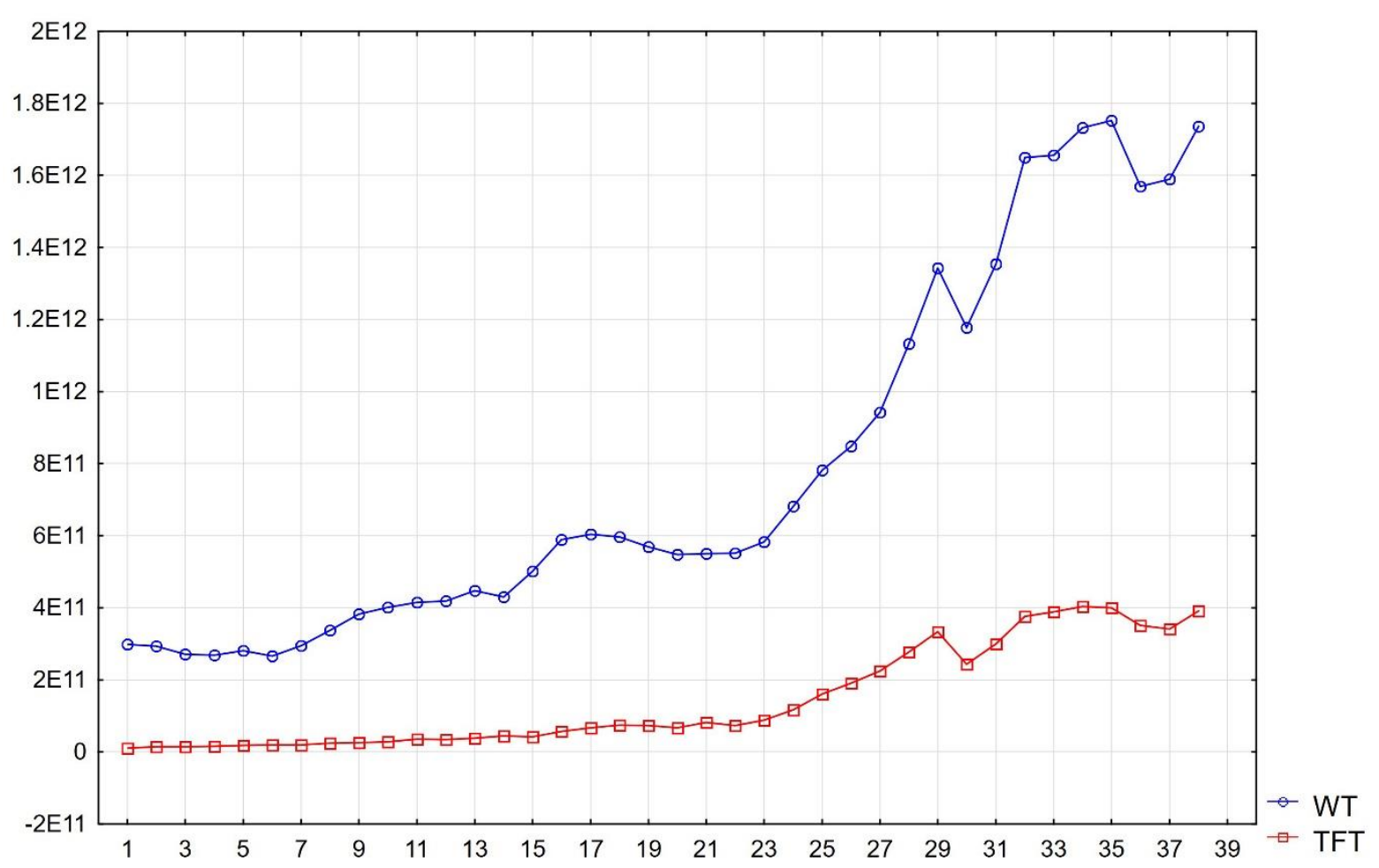

Figure 3 (line-plot ) shows the distributions of the two variables on an annual basis (1980 - 2017). While the TFT variable shows a distribution in a horizontal and narrowband, the WT variable shows a distribution in a wider band. Both variables show an increasing trend over the years. In particular, although upswings and downswings have been observed in both TFT and WT in the last 10 years, the fluctuations in the value movements of TFT are less volatile in this period.

In order to mathematically represent the relationship between TFT and WT, a regression model was created where the dependent variable is TFT and the independent variable is WT.

\section{General Regression Model}

TFT $=-71770861089,5+0,274433558982 * \boldsymbol{W T}$

The direction and level of WT's contribution to the model are given in Table 2. The contribution is significant at a confidence level of alpha $=0.05$.

Table 2: Parameter Estimates (DATA_1980-2017_TRADE)

\begin{tabular}{lllllllll}
\hline Variable & TFT (Param.) & $\begin{array}{l}\text { TFT } \\
\text { Err) }\end{array}$ & $\begin{array}{l}\text { (Std. } \\
\text { TFT (t) }\end{array}$ & $\begin{array}{l}\text { TFT } \\
\text { value) }\end{array}$ & $\begin{array}{l}\text { (P- } \\
\text { TFT } \\
(\boldsymbol{B}))\end{array}$ & $\begin{array}{l}\text { (Beta } \\
\text { TFT } \\
\text { Err.ß) }\end{array}$ & (Std. \\
\hline Intercept & $-7,177086 \mathrm{E}+10$ & $5,231271 \mathrm{E}+09$ & $-13,7196$ & 0,0001 & & & \\
WT & $2,744336 \mathrm{E}-01$ & $5,604023 \mathrm{E}-03$ & 48,9708 & 0,0001 & 0,992578 & 0,020269 \\
\hline
\end{tabular}

Table 3 shows the statistical values on the success of the created model. The data disclosure rate of the model is $9 \%, 9.2 \%, 98.5 \%$, and $98.4 \%$ for $\mathrm{R}$, R-squared, and adj. R-squared respectively.

Table 3: Test SS Model (DATA_1980-2017_TRADE)

\begin{tabular}{lllllllll}
\hline Dependent Var. $\mathbf{R}$ & $\mathbf{R}^{2}$ & Adj. $\mathbf{R}^{2}$ & SS (Model) & $\begin{array}{l}\text { df } \\
\text { (model) }\end{array}$ & MS (Model) & F & $\begin{array}{l}\text { P- } \\
\text { value }\end{array}$ \\
\hline TFT & 0,992578 & 0,985210 & 0,984800 & $7,296721 \mathrm{E}+23$ & 1 & $7,296721 \mathrm{E}+23$ & 2398,141 & 0,00 \\
\hline
\end{tabular}

In addition, the Univariate Test of Significance was applied to the model. The results are shown in Table 4.

The test results also show that the model is successful and the error rate is negligible. 
Table 4: Univariate Tests of Significance (TFT) (DATA_1980-2017_TRADE)

\begin{tabular}{llllll}
\hline Effect & SS & DF & MS & F & P-value \\
\hline Intercept & $5,727102 \mathrm{E}+22$ & 1 & $5,727102 \mathrm{E}+22$ & 188,227 & 0,000000 \\
WT & $7,296721 \mathrm{E}+23$ & 1 & $7,296721 \mathrm{E}+23$ & 2398,141 & 0,000000 \\
Error & $1,095357 \mathrm{E}+22$ & 36 & $3,042657 \mathrm{E}+20$ & & \\
\hline
\end{tabular}

Figure 4: Scatter-plot (Predicted vs Observed)



Figure 4 shows the dual distribution of predicted and observed values based on the regression model. The fact that the points generally have a linear distribution indicates that the model is successful and can be used in future data prediction processes.

\section{Conclusions}

After the Second World War, the United Nations adopted a very elaborate agreement on tariffs. Total 8 rounds of multilateral free trade negotiations, some of which took many years to complete, have been held since its establishment. . In every round of negotiations held until that date, significant successes have been achieved, especially in terms of liberalization of trade in industrial products. In the Doha Round, agricultural issues play a significant role in the negotiations between the trade blocs. Among the main agenda items of the Doha Round are, rather, the issues that the Uruguay Round failed to resolve. Environment, labor exploitation, market access, state-sponsored trade, agricultural support policies, export subsidies, technical barriers and health standards, and dispute resolution mechanisms can be counted among the most important items on the agenda.

The current number of members of the Organization is 155 , and membership negotiations are ongoing for approximately 30 countries. The basic principles of the WTO are: Non-discrimination; Most favored nation; National treatment; Reciprocity; Transparency; Communications, trade policy review, etc.; Binding 
commitments; Connecting tariffs and converting non-tariff barriers to tariffs; Protection provisions, antidumping,etc.

Turkey, which is among the WTO members, has fulfilled its commitments stipulated in the "Uruguay Round" agreements. Although Turkey is in the WTO's group of Developing Countries (DEs), it goes far beyond the Uruguay Round commitments within the framework of the Customs Union completed with the EU as of 01.01.1996 and is ahead of other member DEs in liberalizing international trade.

The obstacles to the liberalization of trade are being overcome one by one, and world trade is developing and increasing rapidly. This trend also positively affects Turkey's foreign trade.

In this study, the level and direction of the relationship between WT and TFT were statistically investigated. For this purpose, in addition to some descriptive statistics, correlation calculations and regression relationships were used to observe the relationship.

The results confirm that the TFT is very closely related to the WT and that the WT can be used as an important parameter for understanding the TFT. The correlation between the 38-year World Trade (WT) and Turkey Foreign Trade (TFT) was $99.258 \%$. It is also clear that the calculated correlation value was statistically significant at alpha $=0.05$ level of significance.

The WTO has proved to be the main body of the international trading system and has given confidence to member states, especially through its determination to settle disputes between member states. The WTO has led to a rapid increase in global exports and barriers to global trade have decreased. This has also been triggered by technological developments in the transport and communications sectors. Trade agreements have become widespread. Turkey's trade volume has also played its part. The main finding of this study is that the relationship between Turkey's foreign trade and world trade is highly correlated. Moreover, this relevant movement is expected to continue in the coming years.

\section{References}

1. N. Argın.\& C. Bakkalcı, Türkiye'nin Dış Ticaret Tarihi, 2011.

2. R. Sedillot, Değiş Tokuştan Süpermarkete, 2005.

3. Ministry of Foreign Affairs (MFA), http://www.mfa.gov.tr/dunya-ticaret-orgutu-_dto_tr.mfa, 28.08.2021

4. WTO, www.wto.org, 20.08.2021

5. S. Akman, (2016), “Dış Ticaret Politikası”. In B. Akçay, İ. Göçmen (Eds), Avrupa Birliği, pp.639-673, 2016.

6. M. Acar, \& S. Aytüre, Dünyada ve Türkiye'de Tarım ve Tarım Politikalarının Geleceği, 2014.

7. S. Aytüre, S. \& M. Acar, Türkiye'de Tarım ve 1980'lerde Tarımsal Dönüşüme Yön Verenler, 2018.

8. M. Acar, DTÖ ve AB Işı̆̆ında Türk Tarımının Geleceği, 2006.

9. Tepav, Dünya Ticaret Örgütü ve Türkiye, 2008.

10. Ministry of Trade (MT), https://www.ticaret.gov.tr/dis-iliskiler/cok-tarafli-ve-bolgesel-iliskiler/cok-tarafliiliskiler/dunya-ticaret-orgutu-dto, 20.08.2021

11. Y. K. Öztürk, “Dünya İktisat Tarihinde Dünya Ticaret Örgütü’nün Yeri ve Önemi”, Turkish Studies, Volume 13/22, Summer 2018, pp.437-449,2018.

12. TUIK, www.tuik.gov.tr, 20.07.2021

13. S. Aytüre \& A. Yücel, "Dünya Ticaret Örgütü Çerçevesinde Türkiye ve Dünya Ticaretinin Gelişimi ve Etkileşimi”. XXIII. Milletlerarası Türk Kooperatifçilik Kongresi, Kiev, Ukrayna, 26 - 28 September 2019, pp.80-91, 2019. 